\title{
CollegeNews
}

\section{ACMG Genetics Review Course}

The 2011 ACMG Genetics Review Course will be held June 2-5, 2011 at the Hilton DFW Lakes Executive Conference Center in Grapevine, Texas. This $2 \frac{1}{2}$ day course provides an intense learning environment with exam preparation and general lectures designed to assist genetics healthcare professionals who are seeking to prepare for the initial certification and recertification examinations or to update and reinforce their general knowledge of medical genetics.

Registration fees include attendance at all sessions, Course Syllabus (print and CD versions) PLUS all meals (dinner Thursday evening, breakfast, lunch, dinner and breaks on Friday and Saturday, breakfast, and morning break on Sunday) and a reception on Saturday evening.

Cut-off date for the discounted group hotel rate is May 9, 2011.

Program information and online registration and hotel reservations are now available at www. acmg.net/ACMG Events.

\section{ACMG Laboratory Quality Assurance Committee Announces New Guidelines and Updates}

The ACMG Laboratory Quality Assurance Committee has updated several sections of its virtual laboratory manual, Technical Standards and Guidelines for Clinical Genetics Laboratories. A new section on High Resolution Melting is now Section G8.10 in the Clinical Molecular Genetics Section, and can be accessed at www.acmg. net/Publications/Laboratory Standards and Guidelines. Additionally, Section 8.4, which describes the Oligonucleotide Ligation Assay, has been updated in the section cited above as well as in Section 3.2.3.4 of the Technical Standards and Guidelines for CFTR Mutation Testing, and can be also accessed at www.acmg.net/ Publications/ Laboratory Standards and Guidelines.

Forthcoming issues of Genetics in Medicine will feature Technical Standards and Guidelines for Spinal Muscular Atrophy Testing, Interpretation and Reporting of Postnatal Constitutional Copy Number Variants (CNVs), and in situ Fluorescence Hybridization Testing (FISH), which will update Cytogenetics Section E9.

\section{ACMG Employment Resource Center}

Your new resource for finding the right medical genetics position or professional is here; ACMG's new Employment Resource Center. Our new online employment resource is open to anyone with an interest in the medical genetics profession generating more opportunities for job seekers and employers. The new site is fully automated, easy to use and makes automatic posting and renewal a breeze. Best of all, you can sign up to receive automatic email notifications regarding positions available and qualified candidates that meet your criteria.

Log on to http://careers.acmg.net today to post your resume, search for available positions or post a new employment opportunity.

Members Receive a significant discount on employment postings.

Job Seekers Post your resume for free today!

Employers Access and recruit specialized pools of genetics professionals. 
Michael S. Watson, PhD, FACMG Recipient of Inaugural ACMG/ACMG Foundation Presidents' Award

The ACMG and ACMG Foundation Presidents' Award has been newly established to thank and honor the valuable contributions made by a member of the American College of Medical Genetics. In a surprise announcement, Michael S. Watson, $\mathrm{PhD}$, FACMG was named the first recipient of this new honor during the Presidential Plenary session at the 2011 ACMG Clinical Genetics Meeting in Vancouver, British Columbia in March.

"Despite the surprise, I am honored to have been the first recipient of this award. As with any award, thanks have to go to those who have allowed success to be realized including the many Boards of Directors and Committees of ACMG with which I have worked, the marvelous staff of the ACMG and ACMGF and the members of ACMG who work daily to deliver genetic services to patients," said Dr. Watson.

For the full announcement, see www.acmg.net.

\section{ACMG Announces President-Elect and New Directors}

The ACMG announced the election of four new Directors who began their terms on April 1, 2011. Directors are elected by the entire ACMG membership and approved by the current Board of Directors.

Gail E. Herman, MD, PhD, FACMG is the new President-Elect. Dr. Herman is a Principal Investigator, Center for Molecular \& Human Genetics, The Research Institute at Nationwide Children's Hospital, Columbus, Ohio and Professor, Department of Pediatrics, The Ohio State University, Columbus, Ohio.
Three additional Directors elected to the Board include: Mira Irons, MD, FACMG, Childrens Hospital of Boston as ACMG Clinical Genetics Director; Christa Lese Martin, PhD, FACMG, of Emory University School of Medicine, Atlanta, GA as ACMG Cytogenetics Director; and Soma Das, PhD, FACMG, University of Chicago as ACMG Molecular Genetics Director.

Directors completing their terms with the ACMG Board in 2011 include Past President Joe Leigh Simpson, MD, FACMG; Secretary and Molecular Genetics Director Elaine B. Spector, PhD, FACMG; Treasurer and Cytogenetics Director Daynna J. Wolff, PhD, FACMG; and Clinical Genetics Director Gerald Feldman, MD, PhD, FACMG.

All newly elected Directors will serve 6-year terms from 2011 - 2017.

\section{Outgoing Committee Chairs}

We would like to acknowledge the hard work and efforts of the following individuals who served as chairs on ACMG Committees and whose terms were completed in March 2011.

Outgoing Committee Chairs:

Helga Toriello, Chair

Professional Practice and Guidelines Committee

April 2007 - March 2011

Mira Irons, Chair

Education \& CME Committee

April 2009 - March 2011

Lori Potocki, Chair

2011 Program Committee

March 2010 - April 2011

The ACMG extends a heartfelt thanks to these hard working individuals. 